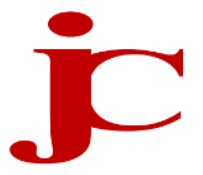

Jurnal Civics: Media Kajian Kewarganegaraan

https://journal.uny.ac.id/index.php/civics/index

1829-5789 (print)

2541-1918 (online)

\title{
Penanaman nilai-nilai Pancasila pada kehidupan santri di pondok pesantren
}

\author{
Hendri $^{\text {a, } 1}$, Cecep Darmawan b, 2, Muhammad Halimi ${ }^{\text {c, } 3}$ \\ a, b, c Departemen Pendidikan Kewarganegaraan, Universitas Pendidikan Indonesia, Bandung, \\ Indonesia \\ 1'hndr270388@gmail.com; ${ }^{2}$ cecepdarmawan@upi.edu; ${ }^{3}$ mhalimi58@gmail.upi.edu \\ *korespondensi penulis
}

\begin{tabular}{|c|c|c|}
\hline \multicolumn{2}{|l|}{ Informasi artikel } & \multirow{2}{*}{$\begin{array}{l}\text { ABSTRAK } \\
\text { Generasi bangsa harus mampu mengimplementasikan nilai- nilai }\end{array}$} \\
\hline Sejarah artikel: & & \\
\hline Diterima & : 09-02-2018 & \multirow{4}{*}{$\begin{array}{l}\text { Pancasila sebagai pandangan hidup, hal tersebut dapat dilakukan dengan } \\
\text { berbagai cara dan lembaga, salah satunya yaitu di pesantren. Penelitian } \\
\text { ini bertujuan untuk mendeskripsikan dan menganalisis aktivitas } \\
\text { pesantren dalam menanamkan nilai- nilai Pancasila pada kehidupan } \\
\text { santri. Jenis penelitian menggunakan pendekatan kualitatif. Teknik } \\
\text { pengumpulan data dilakukan dengan observasi, wawancara dan studi } \\
\text { dokumentasi. Kesimpulannya adalah santri di pesantren Syaikhona Moh. } \\
\text { Cholil Bangkalan menanamkan nilai-nilai Pancasila, sebagai sumber } \\
\text { menjalin hubungan yang baik dengan sesamanya. Salah satunya melalui } \\
\text { Pendidikan dan program- program pesantren yang mencerminkan nilai- } \\
\text { nilai Pancasila. }\end{array}$} \\
\hline Revisi & : 20-03-2018 & \\
\hline Dipublikasikan & : 31-10-2018 & \\
\hline \multirow{2}{*}{\multicolumn{2}{|c|}{$\begin{array}{l}\text { Kata kunci: } \\
\text { santri } \\
\text { pesantren } \\
\text { pancasila }\end{array}$}} & \\
\hline & & ABSTRACT \\
\hline \multicolumn{2}{|l|}{$\begin{array}{l}\text { Keywords: } \\
\text { student } \\
\text { boarding school } \\
\text { pancasila }\end{array}$} & $\begin{array}{l}\text { The young generation of the nation must be able to implement the values } \\
\text { of Pancasila as a way of life. This can be done in various ways and } \\
\text { institutions, one of which is in pesantren. This study aims to describe and } \\
\text { analyze the activities of pesantren in instilling Pancasila values in the } \\
\text { lives of santri. This type of research uses a qualitative approach. Data } \\
\text { collection techniques are carried out by observation, interviews and } \\
\text { documentation studies. The conclusion is the santri in the pesantren } \\
\text { Syaikhona Moh. Cholil Bangkalan instilled the values of Pancasila, as a } \\
\text { source of establishing good relations with each other. One of them is } \\
\text { through education and pesantren programs that reflect the values of } \\
\text { Pancasila. }\end{array}$ \\
\hline
\end{tabular}

\section{Copyright $\odot 2018$ Hendri, dkk}

\section{Pendahuluan}

Pancasila sebagai dasar negara merupakan kesepakatan politik ketika negara Indonesia didirikan melalui sidang BPUPKI yang dihadiri dari berbagai utusan, baik dari utusan Islam maupun non-Islam. Pancasila merupakan pandangan hidup bangsa Indonesia. Pancasila artinya lima dasar atau lima asas yaitu nama dari dasar negara kita, Negara Republik Indonesia. Istilah Pancasila telah dikenal sejak zaman Majapahit pada abad 17 yang terdapat dalam buku Nagara Kertagama karangan Prapanca dan buku Sutasoma karangan Tantular. Dalam buku Sutasoma ini, Pancasila selain mempunyai arti "berbatu sendi yang lima" (dari bahasa Sangsekerta) Pancasila juga mempunyai arti "pelaksanaan kesusilaan yang lima" (Pancasila Krama), yaitu sebagai 1) tidak boleh melakukan kekerasan; 2) tidak boleh mencuri; 3) tidak boleh berjiwa dengki; 4) tidak boleh berbohong, dan; 5) tidak boleh mabuk minuman keras/obat-obatan terlarang (Surip, Syarbaini, \& Rahman, 2015, hal. 1820). Menurut Latif (2015) angka "lima" bukan hanya sebagai simbolis, angka lima merupakan integritas dari keyakinan bangsa Indonesia. Dilihat dari segi agama, misalnya, rukun Islam ada lima, salat wajib ada lima (magrib, isya, subuh, zuhur, dan asar) yang 
dikerjakan sehari semalam. Tokoh pandawa juga lima. Bukan hanya itu, angka lima memang memberikan hal yang berbeda bagi bangsa Indonesia.

Pada tanggal 18 Agustus 1945 Pancasila ditetapkan sebagai dasar negara, maka nilainilai kehidupan dalam berbangsa dan bernegara sejak saat itu haruslah berdasarkan pada Pancasila. Pancasila sebagai konsensus nasional yang dapat diterima oleh semua paham, golongan, dan kelompok masyarakat di Indonesia. Oleh karenanya, suatu keniscayaan bahwa Pancasila difungsikan dalam setiap elemen kelembagaan, pendidikan, kebudayaan, dan organisasiorganisasi di Indonesia. Misalnya pesantren sebagai pendidikan tertua di Indonesia sangat berkembang pesat dan besar. Perkembangannya pun tidak hanya pada tekstual, namun lebih mengikuti perkembangan zaman, dengan tujuan mempersiapkan siswa atau santri lebih maju, bukan hanya ahli di bidang agama, namun tentang kepemerintahan juga digalakkan dengan diadakan Pendidikan-pendidikan di pesantren.

Pesantren sendiri secara etimologis berasal dari kata dasar santri yang dengan awalan pe di depan dan akhiran "an" di belakang berarti tempat tinggal santri. Pesantren menjadi tempat dari para santri untuk mendapatkan pengetahuan dan ajaran agama dari seorang ulama atau kiai. Dalam praktik pengajarannya, pondok pesantren memiliki konsep pengajaran agama Islam berdasarkan kepada Alquran dan hadis, juga kita-kitab Islam seperti Safinah, Taklimu Mutaallim, dan kitab lainnya yang merupakan karya dari tokoh Islam (Atabik, 2014). Pesantren adalah institusi pendidikan yang berada di bawah pimpinan seorang atau beberapa kiai/ulama dan dibantu oleh seorang santri senior serta beberapa anggota keluarganya. Pesantren menjadi bagian penting bagi kiai sebab pesantren dapat difungsikan sebagai tempat untuk berdakwah, mengembangkan, dan melestarikan ajaran Islam.

Namun, dewasa ini Pancasila masih saja dipertentangkan, seakan-akan Pancasila masih belum menemukan titik terang di hati bangsanya sendiri. Pancasila masih diperdebatkan oleh banyak kalangan termasuk umat sebagian umat muslim di Indonesia. Seakan Pancasila tidak tepat dijadikan dasar bagi mayoritas umat Islam. Seperti ungkapan "luka lama hidup kembali" luka yang ditimbun dengan kata sepakat diolah kembali oleh orang-orang yang berpikir prematur dalam memahami Pancasila dan Islam pada masa kini. Seakan ulama-ulama terdahulu, yang ikut serta dalam perumusan Pancasila tidak memiliki pemahaman Islam yang hakiki, dengan menerima Pancasila sebagai dasar negara bukan Alquran dan hadis Nabi.

Berdasarkan uraian di atas, dengan berbagai data dan fakta, jika suatu pesantren melakukan upaya penanaman nilai-nilai Pancasila pada kehidupan santri, maka santri bukan hanya nampak identitasnya sebagai orang yang beragama, namun, identitas kewarganegaraannya juga semakin jelas. Kepatuhan santri berdasarkan yang digariskan Pancasila, menjadi cerminan santri adalah warga negara yang baik. Dengan hal tersebut, bahwa Pancasila sebagai kristalisasi dari agama Islam memang tidak diragukan lagi.

\section{Metode}

Pendekatan yang digunakan dalam penelitian ini adalah pendekatan kualitatif karena akan perilaku manusia dalam kehidupan sehari-hari di pesantren. Metode yang digunakan dalam penelitian ini yaitu metode studi kasus. Studi kasus ini tidak mengambil generalisasi, sebab kesimpulan yang diambil merupakan kekhasan dari latar yang diteliti (Danial, 2009). Sumber data dari penelitian ini diperoleh dari data lapangan dan kepustakaan. Data lapangan berupa hasil observasi atau pengamatan langsung dan wawancara kepada para informan. Proses pengumpulan data dilakukan oleh peneliti melalui empat teknik pengumpulan data, yaitu: observasi, wawancara, studi dokumentasi dan studi literature. Analisis data dalam penelitian kualitatif terdiri atas tiga alur kegiatan yang dilakukan secara bersamaan yaitu: reduksi data, sajian data, dan penarikan kesimpulan/verifikasi (Creswell, 2010). 


\section{Hasil dan Pembahasan}

Pondok Pesantren Syaikhona Moh. Cholil terletak di Kabupaten Bangkalan Jawa Timur, Madura paling barat. Pesantren yang didirikan pada tahun $1861 \mathrm{M}$ oleh embah Kholil (K.H. Kholil bin Abdul Latif) secara geografis terletak di Jl. KH. Moh. Kholil no. 1-6 Kelurahan Demangan, Kecamatan Bangkalan, Kabupaten Bangkalan. Pendidikan di pesantrennya bertujuan untuk meningkatkan prestasi belajar dan kemuliaan akhlak santri salah satunya melalui kegiatan ekstrakurikuler. Santri diberikan berbagai keterampilan seperti menjahit, mengelola koperasi pesantren, berdakwah, bahkan ada yang dilatih menjadi jurnalis. Pemberian keterampilan tersebut untuk meningkatkan wawasan pengetahuan dan pola pikir kritis serta keterampilan santri. Tidak hanya itu, ilmu yang di peroleh di pesantren dapat dikembangkan di kehidupan sehari-hari. Namun menjadi prioritas dari tujuan pendidikan pesantren ini yakni menekankan pada perubahan sikap, etika yang mencerminkan nilai-nilai Pancasila, dari nilai sila ketuhanan, kemanusiaan, persatuan, musyawarah, dan keadilan yang dijadikan landasan hidup bersama oleh santri di pesantren. Pondok pesantren hadir untuk menjadi alternatif pemenuhan kualitas manusia Indonesia dalam hal keimanan dan ketakwaan serta pemenuhan kecakapan hidup yang berkualitas di dunia dan di akhirat (Arpannudin, 2016) Di samping itu, sangat dianjurkan dalam ajaran Islam tentang akhlak sebagai khazanah lambang keilmuan orangorang Islam.

Visi pondok pesantren ini yaitu terciptanya santri yang berilmu, beriman, dan bertakwa berjuang dan beramal saleh yang dilandasi nilai-nilai akhlak. Sedangkan misinya meliputi: 1) membangun dan mengembangkan semangat untuk belajar; 2) mengembangkan pola pikir yang kreatif, dinamis, dan berwawasan luas; 3) mengembangkan pemahaman, dan pengamalan akidah dan ajaran Islam yang komprehensif; 4) membangun dan mengembangkan manajemen partisipatif; 5) meningkatkan sistem dan metode pembelajaran.
Aktivitas yang menjadi rutinitas dalam ranah pendidikan meliputi pendidikan formal dari tingkat Madrasah Tsanawiah (MTs) hingga pada perguruan tinggi strata 1 (S1) yang dilaksanakan dari siang hari hingga sore. Sedangkan pendidikan nonformal meliputi madrasah diniah, sanawiah, dan aliah dilaksanakan dari pagi hingga siang. Untuk aktivitas yang menjadi program pesantren dilaksanakan di malam hari misalnya amalanalaman, belajar wajib, musyawarah, dan sebagainya. Dari visi dan misi serta tujuan pesantren tersebut, bahwa di pesantren cara menanamkan nilai-nilai Pancasila meliputi pendidikan setinggi-tingginya dengan tujuan agar mendapatkan pengetahuan yang luas serta menciptakan manusia yang kritis dan inovatif. Kebiasaan untuk taat aturan merupakan konsekuensi yang harus ditaati oleh para santri di pesantren.

Ditinjau dari visinya, peran pesantren dalam menanamkan nilai-nilai Pancasila pada kehidupan santri di pesantren terdapat dua aspek. Pertama. penanaman nilai-nilai Pancasila melalui aspek pendidikan di pesantren yang mengarah pada bentuk kesadaran santri untuk mengamalkan nilainilai Pancasila. Pendidikan yang dilaksanakan di pesantren ini terdiri dari dua bagian, yaitu (1) melalui pendidikan formal. Pendidikan ini berkembang di pesantren karena kesadaran pesantren terhadap masa depan santri harus bergerak masif di dunia akademisi dan birokrasi, sehingga pesantren merasa perlu untuk melengkapi pengetahuan santri dengan ilmu umum seperti pendidikan formal di luar pesantren. Misalnya tentang Pendidikan Kewarganegaraan, Ilmu Pengetahuan Sosial serta, Bahasa Indonesia, Bahasa Inggris, dan mata pelajaran lainnya yang ikut dalam menginterpretasikan kesadaran bangsa santri dalam ber-Pancasila. (2) melalui pendidikan nonformal. Pendidikan ini memang pada dasarnya menjadi acuan serta prioritas setiap pesantren untuk menciptakan manusia paham tentang ilmu agama. Mata pelajaran yang diajarkan misalnya tentang ilmu hadis, tauhid, fikih, akhlak, serta tafsir Alquran. Semua mata pelajaran tersebut dikembangkan di pesantren dengan tujuan santri menjadi manusia berpengetahuan luas khususnya di 
bidang ilmu agama serta mempunyai kepribadian, akhlak, serta jiwa sosial yang tinggi. Sebagaimana yang menjadi acuan dalam ajaran Pesantren bahwa bentuk luasnya ilmu dapat dilihat dari kemuliaan akhlaknya.

Kedua, di luar ranah pendidikan, pesantren juga menerapkan aktivitas yang membangun kesadaran berpancasila. Aktivitas tersebut merupakan program kegiatan rutin yang menjadi kewajiban para santri setiap harinya. Misalnya harus salat fardu berjamaah, kegiatan musyawarah dalam memecahkan masalah pelajaran atau masalah umum di luar pelajaran. Di samping itu, harus taat aturan dengan tidak boleh terlambat dalam mengikuti aktivitas di pesantren yaitu menghargai ketepatan waktu, membangun kesadaran mandiri, menjaga kebersihan lingkungan dengan adanya piket kebersihan, kerja bakti setiap seminggu sekali, saling membantu, menghargai, saling menghormati, tidak boleh saling mencaci maki. Semua tersebut merupakan bentuk peran pesantren dalam menanamkan pembiasaan pengamalan nilai-nilai Pancasila.

Penanaman nilai-nilai Pancasila pada kehidupan tidak terlepas dari peran pendidikan kewarganegaraan. Sapriya \& Wahab (2011) mengatakan bahwa warga negara yang baik adalah warga negara yang memahami dan melaksanakan hak-hak dan kewajiban, bertanggung jawab, menghargai hak-hak orang lain, taat hukum, serta bayar pajak. Tidak sampai di situ, Yunita (2016) mengatakan, untuk menjadi warga negara yang baik juga harus bisa mempertahankan serta berperan aktif dalam menjaga stabilitas negara, salah satunya dengan menjaga keutuhan bangsa dengan menanamkan nilainilai Pancasila pada kehidupan berbangsa dan bernegara. Upaya ini dilakukan untuk membangun sebuah ketahanan, stabilitas negara dari pemahaman ekstremisme yang akan membuat bangsa Indonesia berpecah belah, saling membenci, intolerann, diakibatkan karena pengamalan Pancasila tidak dijadikan landasan dalam berbangsa dan bernegara.

Tujuan pendidikan pesantren yaitu untuk menciptakan manusia yang selalu menaati perintah Allah dan menjauhi larangan-Nya dengan bekal ilmu agama yang baik. Contohnya adalah beribadah dengan tekun, saling tolong menolong di dalam kehidupan, menjaga kebersihan lingkungan, taat aturan baik dalam lingkungan pesantren atau di luar, saling memaafkan, dianjurkan untuk berakhlak baik, saling menghormati, saling menjaga, saling menghargai, saling mengingatkan, saling mengayomi, saling menutupi kekurangan yang terdapat pada saudara-saudaranya (teman) di pesantren, dan saling berbagi ilmu pengetahuan tanpa harus mengharap imbalan. Semua tersebut adalah bagian dari hal yang diterapkan dalam kehidupan santri di pesantren. Nursavitri (2013, hal. 58 ) dalam hal ini berpendapat bahwa untuk bisa hidup dalam masyarakat yang multikultural, paling tidak ada empat sikap, yaitu: 1) inklusifisme, diartikan sebagai suatu sikap yang lapang dada; 2) humanisme, artinya adalah menilai semua manusia sama derajatnya, tidak memandang ras, warna kulit, agama, dan lain-lain; 3) toleransi, dapat diartikan pula sebagai sikap yang menghargai dan menghormati perbedaan yang dimiliki tiap manusia; dan 4) demokrasi, dapat diartikan sebagai kebebasan individu untuk mengemukakan pendapatnya, dengan kata lain harus ada kebebasan berpikir. Dari keempat sikap tersebut dapat disimpulkan bahwa semua bentuk perilaku yang terdapat di Pesantren Syaikhona Moh. Cholil tersebut merupakan cerminkan dari nilai-nilai yang ada dalam Pancasila dan dapat dijadikan teladan bagi lembaga lainya.

Bentuk-bentuk perilaku yang mencerminkan nilai-nilai Pancasila pada kehidupan santri di di pesantren Syaikhona di antaranya seperti mengikuti program-program di pesantren, misalnya, salat wajib 5 waktu, salat sunah, membaca Al-quran, membaca nadham, mengikuti kegiatan istigasah, kesadaran dalam menaati peraturan di pesantren, harus jujur, adil, mandiri, akur, toleransi, saling membantu, gotong royong, giat belajar, menjaga kebersihan, kesopanan, ketaatan, cinta tanah air, turut mengikuti upacara bendera.

Dalam ranah pendidikan, tidak terlambat masuk kelas, rajin belajar, berpakaian rapi, menjaga kesopanan, menghormati guru, taat 
pada guru, tidak mencemarkan nama baik akademik atau lembaga, tidak melanggar apa yang menjadi peraturan sekolah dan pesantren. Selain menjaga ketaatan pada peraturan lembaga, pesantren juga menekankan setiap ketentuan yang ada di dalam agama Islam, seperti dilarang minum minuman keras, mencuri, berzina, membangkang pada pemimpin (umara'), dan menuntut untuk selalu patuh dalam perintah Allah Swt.

Pancasila memiliki nilai-nilai yang apabila diamalkan, maka dapat menjadi fondasi yang kuat dalam membangun bangsa Indonesia ke arah yang lebih baik (Chairiyah, 2014, hal. 59 ). Pesantren Syaikhona Moh. Cholil Bangkalan dalam menanamkan nilainilai Pancasila pada kehidupan santri di Pesantren melalui pendidikan-pendidikan yang mengarah pada bentuk kesadaran santri untuk ber-Pancasila ditopang dengan pendidikan formal lebih mengenal teori tentang Pancasila, fungsi, dan tujuannya. Misalnya tentang Pendidikan Pancasila dan Kewarganegaraan, Ilmu Pengetahuan Sosial, Bahasa Indonesia, Bahasa Inggris, dan mata pelajaran lainnya yang ikut dalam menginterpretasikan kesadaran bangsa (santri) dalam ber-Pancasila. Sedangkan pendidikan nonformal adalah pendidikan yang pertama kali berkembang di setiap Pesantren. Pendidikan ini orientasinya pada pengembangan tentang ilmu agama. Dari pendidikan agama ini lah berdampak positif dalam kesadaran santri di Pesantren untuk berperilaku yang mencerminkan Pancasila, sebagai optimalisasi ajaran Islam yang rahmatan lil'alamin.

Pendidikan pesantren juga menerapkan aktivitas yang membangun kesadaran berPancasila. Aktivitas tersebut merupakan program kegiatan rutin yang menjadi kewajiban para santri setiap harinya. Misalnya harus salat fardu berjamaah, kegiatan musyawarah dalam memecahkan masalah pelajaran bahwa permasalahan yang di luar pelajaran. Di samping itu, harus taat aturan dengan tidak boleh terlambat dalam mengikuti aktivitas di Pesantren, membangun kesadaran mandiri, menjaga kebersihan lingkungan dengan adanya piket kebersihan, kerja bakti setiap minggu sekali, saling membantu, menghargai, saling menghormati, tidak boleh saling mencaci maki, penuh dengan kedamaian, persatuan, persaudaraan sebagai bentuk ukhuwah islamiyah wa insaniyah. Pesantren masih kental dalam merawat budaya-budaya yang dipertahankan ulama terdahulu yaitu persatuan dan kesatuan (Baso, 2012). Terciptanya kemerdekaan dikarenakan persatuan dan kesatuan saling kuat, budaya seperti itu terdapat di pesantren, yang merupakan aset paling berharga karena dalam menjaga persaudaraan, menghormati, tolong menolong, persatuan, dan gotong royong sampai sekarang masih terawat sedangkan di luar mulai terkikis oleh perkembangan zaman.

Perilaku yang mencerminkan nilai-nilai Pancasila di pesantren merupakan miniatur budaya yang ada di Indonesia ras, suku, serta budaya. Namun, di pesantren hanya terdapat ajaran yang berbasis Islam, sesuai dengan later belakang pesantren adalah pendidikan Islam pertama kali di Indonesia. Pola dalam mengamalkan nilai Pancasila santri dapat diimbangi dengan pengetahuan yang luas untuk memahami arti sila pertama. Menghargai agama orang lain dalam pendidikan pesantren sudah diterapkan mulai dulu oleh para ulama. Bukti yang nyata adalah terciptalah sebuah persatuan yang dikemas dengan kesepakatan Pancasila sebagai dasar negara. Pancasila merupakan sublimasi nilainilai budaya yang menyatukan masyarakat Indonesia beragam suku, ras, bahasa, agama, pulau, menjadi bangsa yang satu, damai dan tenteram tidak ada permusuhan antara satu dan yang lain (Rachmah, 2013). Nilai-nilai yang terkandung dalam Pancasila tersebut sebagai berikut.

Sila ketuhanan yang Maha Esa, yang mengandung arti pengakuan adanya kuasa prima (sebab pertama) yaitu Tuhan yang Maha Esa, menjamin penduduk untuk memeluk agama masing-masing dan beribadah menurut agamanya, tidak memaksa warga negara untuk beragama, menjamin berkembang dan tumbuh suburnya kehidupan beragama, bertoleransi dalam beragama, dalam hal ini toleransi ditekankan dalam 
beribadah menurut agamanya masing-masing (Tukiran \& Udhie, 2014).

Sila kedua manusia memiliki hakikat pribadi yang mono-pluralis terdiri atas susunan kodrat jiwa raga, serta berkedudukan sebagai makhluk pribadi yang berdiri sendiri dan makhluk Tuhan Yang Maha Esa. Nilai luhur kemanusiaan akan menumbuhkan sikap harmonis, menghormati hak asasi manusia, anti penjajahan, mengutamakan kebenaran dan keadilan, mencintai sesama manusia, tenggang rasa, dan sebagainya (Surip et al., 2015)

Sila ketiga berupa pengakuan terhadap hakikat satu tanah air, satu bangsa, dan satu negara Indonesia, tidak dapat dibagi sehingga seluruhnya merupakan suatu keseluruhan dan keutuhan. Nilai luhur persatuan terkandung di dalamnya cinta tanah air, tidak membedabedakan sesama warga negara Indonesia, cinta perdamaian dan persatuan, tidak mengagung-agungkan bangsa sendiri, suku, dan daerah tertentu (Tukiran \& Udhie, 2014).

Sila keempat sebuah kalimat yang secara bahasa membahasakan bahwa Pancasila pada sila keempat adalah penjelasan negara demokrasi. Dengan analisis ini diharapkan akan diperoleh makna yang akurat dan mempunyai nilai filosofis yang diimplementasikan secara langsung dalam kehidupan bermasyarakat. Tidak hanya itu, sila ini menjadi banyak acuan dari setiap langkah pemerintah dalam menjalankan setiap tindakannya. Yaitu menjunjung dan mengakui adanya rakyat yang meliputi keseluruhan jumlah semua orang warga dalam lingkungan daerah atau negara tertentu yang segala sesuatunya berasal dari rakyat dilaksanakan oleh rakyat dan diperuntukkan untuk rakyat.

Sila kelima mengakui hakikat adil berupa pemenuhan segala sesuatu yang berhubungan dengan hak dalam hubungan hidup kemanusiaan. Nilai luhur yang terkandung di dalamnya adalah mencintai keadilan sosial, cinta kekeluargaan, suka bekerja keras, menghormati kedaulatan bangsa lain, dan menganggap bangsa lain sederajat (Kaelan, 2013). Sila pertama menjiwai dan mendasari sila kedua, ketiga, keempat, dan kelima; sila kedua dijiwai dan didasari sila pertama, menjiwai dan mendasari sila ketiga, keempat, dan kelima; sila ketiga dijiwai dan didasari sila pertama dan sila kedua, menjiwai dan mendasari sila keempat dan kelima; sila keempat dijiwai dan didasari sila pertama, kedua, dan ketiga, menjiwai dan mendasari sila kelima; dan sila kelima dijiwai dan didasari sila pertama, kedua, ketiga, dan keempat. Itulah yang dinamakan Pancasila hierarkis piramidal.

Hal-hal pendorong yang menjadi alat terlaksanakannya penerapan nilai-nilai Pancasila di pesantren diantaranya adanya pendidikan di Pesantren formal dan nonformal merupakan faktor utama dalam membentuk kesadaran santri terhadap pentingnya nilai-nilai Pancasila di kehidupan pesantren. Dalam pendidikan formal terdapat pembelajaran langsung tentang Pancasila, fungsi, tujuan, serta manfaat penerapan nilainilai Pancasila pada kehidupan. Selanjutnya pendidikan nonformal diajarkan tentang nilainilai keislaman dan akhlak manusia kepada Tuhan dan makhluk Ciptaan-Nya.

Faktor lain yang mendukung terbentuknya nilai-nilai Pancasila pada kehidupan santri adalah program-program yang dibentuk oleh pesantren meliputi kajiankajian tentang kebangsaan, antikorupsi, penyuluhan sosialisasi empat pilar MPR RI yang kerap kali pesantren melibatkan santri sebagai utusan untuk menghadiri acara seminar nasional tersebut. Pesantren mengembangkan seperti media cetak informasi seputar kajian Islam dan kajian tentang perkembangan birokrasi, politik, ekonomi, pendidikan, dan kajian tentang pelanggaran- pelanggaran yang terjadi di pemerintahan sebagai salah bentuk kesadaran berpancasila.

Pesantren setiap hari nasional selalu mengagendakan upacara bendera merah putih. Misalnya, pada hari kemerdekaan bangsa Indonesia yaitu pada tanggal 17 Agustus, hari santri nasional. Semua tersebut dibentuk agar para santri tertanam kesadaran cinta tanah air, rasa nasionalisme hingga menjadi santri yang Pancasilais yaitu mengamalkan nilai-nilai Pancasila pada kehidupan sehari-harinya.

Kendala yang dihadapi dalam meningkatkan berpancasila yaitu dengan 
menanamkan nilai-nilai Pancasila pada kehidupan santri terdapat dua faktor, yaitu dari diri sendiri dan pengaruh dari lingkungan sekitar. Pengaruh diri sendiri karena kurangnya kesadaran dikarenakan terbatasnya tenaga yang ada. Sedangkan pengaruh dari luar yaitu dengan bergulirnya waktu dan perkembangan zaman yang semakin modern. Selain itu terbatasnya sarana dan prasarana yang ada di pesantren memberi dampak negatif untuk terinternalisasinya nilai-nilai Pancasila pada kehidupan santri.

Penerapan nilai-nilai Pancasila pada kehidupan santri di pesantren terdapat kendala, sehingga bagian kecil para santri terkadang tidak dapat mengimbangi aktivitas dan hal-hal yang mendukung perkembangan nilai-nilai Pancasila pada santri. Faktor ini diakibatkan karena kurang pemahaman dan bimbingan intensif pada santri dikarenakan kurang tenaga yang ada di Pesantren Syaikhona Moh. Cholil Bangkalan. Di sisi lain adanya pengaruh-pengaruh dari luar, yang mengakibatkan perilaku santri kurang mencerminkan nilai-nilai Pancasila. Upaya Pesantren dalam mengentaskan permasalahan ini dapat dilakukan dengan hal-hal yang progresif. Misalnya lebih memusatkan pada individu dengan menggunakan pendekatan persuasif, memberi stimulus, arahan, dan juga tindakan-tindakan yang lebih membangun kesadaran santri.

\section{Simpulan}

Penanaman nilai-nilai Pancasila pada kehidupan santri di Pesantren Syaikhona Moh. Cholil Bangkalan dilakukan dengan dua pendekatan yang pertama dengan ranah pendidikan di Pesantren baik formal ataupun nonformal. Kedua melalui program-program yang membentuk aktivitas santri. Program mencakup keseluruhan yang menjadi pedoman santri dalam melakukan kegiatan di Pesantren. Program ini juga merupakan sarana pendukung dalam menanamkan nilai-nilai Pancasila pada kehidupan santri. Sedangkan bentuk-bentuk perilaku santri yang mencerminkan nilai-nilai Pancasila seperti taat ibadah, taat aturan yang dibuat oleh Pesantren, taat peraturan yang dibuat oleh sekolah. Sedangkan bentuk penerapan di lingkungan kehidupan di Pesantren. Misalnya seperti saling tolong menolong, saling menghormati, saling menjaga antara satu dan yang lain, tidak melakukan sesuatu yang merugikan orang lain, saling menghargai perbedaan pendapat, perbedaan suku, etnis, budaya, dan bahasa. Sedangkan faktor penghambat ada dua yaitu terdapat pada diri sendiri dikarenakan kurangnya intensitas dalam pembinaan dan juga pengaruh orang lain. Upaya pembenahan dalam mengatasi masalah ini pesantren selalu melakukan upaya progresif lebih bijak dan masif untuk pembenahan tersebut agar menjadi santri yang Pancasilais.

\section{Ucapan terima kasih}

Terima kasih saya ucapkan atas kerja sama dan masukan terhadap penelitian saya, khususnya kepada teman-teman di Pesantren Syaikhona Moh. Cholil Bangkalan, dewan Asatidz, pengurus, terlebih lagi pada dosen pembimbing yang dengan sabar membimbing hingga selesai studi.

\section{Referensi}

Arpannudin, I. (2016). Implementasi nilai sosial ukhuwah islamiah di pondok pesantren. Humanika, 16(1), 1-21.

Atabik. (2014). Historisitas dan peran pondok pesantren Somalangu di Pesisir Selatan. Ibda' Jurnal Kebudayaan Islam A., 12(2), 185-197.

Baso, A. (2012). Akar pendidikan kewarganegaraan di pesantren. Komnas HAM RI, XVII(4), 162-186.

Chairiyah. (2014). Revitalisasi nilai-nilai Pancasila sebagai pendidikan karakter. Jurnal Pendidikan Ke-SD-an, 1(1), 5462.

Creswell, J. W. (2010). Reseach design. Pendekatan, kualitatif, kuantitatif, dan mixed. Yogyakarta: Pustaka Pelajar.

Danial, E. (2009). Metode penulisan karya ilmiah. Bandung: Laboratorium Pendidikan Kewarganegaraan.

Kaelan. (2013). Negara kebangsaan Pancasila (kultural, historis, filosofis, yuridis, dan aktualisasinya). Yogyakarta: Pradikma.

Latif, Y. (2015). Negara paripurna: 
Historisitas, rasionalitas, dan aktualisasi Pancasila. Jakarta: PT Gramidia Pustaka Utama.

Nursavitri, G. (2013). Pengaruh sikap toleransi terhadap penerapan nilai-nilai Pancasila di rukun warga IV Kelurahan Wonokarto, Wonogiri. Educitizen, 1(1), 57-67.

Rachmah, H. (2013). Nilai-nilai dalam pendidikan karakter bangsa yang berdasarkan Pancasila dan UUD 1945. E-Journal WIDYA Non-Eksakta, 1(1), 714.

Surip, N., Syarbaini, S., \& Rahman, A. (2015). Pancasila dalam makna dan aktualisasi. Yogyakarta: CV. Andi Offset.

Tukiran, T., \& Udhie, H. (2014). Pemimpin berkarakter Pancasila. Bandung: Alfabeta.

Wahab, A. A., \& Sapriya. (2011). Teori dan landasan pendidikan kewarganegaraan. Bandung: Alfabeta.

Yunita. (2016). Pendidikan bela negara (PBN) sebagai wahana pengembangan sikap nasionalsime mahasiswa (Studi pengembangan program pendidikan bela negara pada Universitas Siliwangi Tasikmalaya). Universitas Pendidikan Indonesia. 